\title{
Conservation of Agriculture in the Western Indo-Gangetic Plains' Irrigated Cotton-Wheat and Guar-Wheat System
}

\author{
Dhinu Yadav* and Leela Wati \\ Department of Microbiology, CCS Haryana Agricultural University, Hisar-125004, India \\ *Corresponding author
}

\begin{abstract}
A B S T R A C T
Conserving natural capital and optimizing factor productivity in semi-arid regions has been a great challenge in achieving sustainability of the production system. Cotton-wheat and guar-wheat based cropping system plays a predominant role under evolving climatic scenarios by sustainable conservation of natural resources. In the present study, the effect of long-term zero-tillage practices on selected physico-chemical and microbiological properties was determined in different cropping system at $0-15$ and $15-30 \mathrm{~cm}$ soil depth in Mahendergarh (Tigra) district of Haryana (latitude- $28.03^{\circ} \mathrm{N}$ and longitude- $76.10^{\circ} \mathrm{E}$ ) during the year 2006. The composition of soil samples from traditional and zero-tillage farms had been sandy. After harvesting of wheat in 2017, triplicate soil samples from undisturbed and disturbed soil were obtained for determination of $\mathrm{pH}$, electrical conductivity (EC), soil organic carbon (SOC), total N, P and K content, microbial biomass carbon and nitrogen (MBC and MBN), enzymatic activities and viable count of microbes and results showed that $\mathrm{EC}$ and $\mathrm{pH}$ were not significantly affected by tillage systems. Results indicated that SOC $(0.31 \%)$ under ZT was relatively higher at the surface layer compared to CT $(0.28 \%)$ under guar-wheat cropping system. The long-term zero-tillage practices resulted that relatively higher soil total nitrogen, phosphorous and potassium contents, MBC and MBN dehydrogenase, alkaline phosphatase, cellulase and urease activities and bacterial and fungal count at the $0-15 \mathrm{~cm}$ depth than conventional tillage under guar-wheat cropping pattern. The zero-tillage practices thus enhanced soil's physicochemical as well as microbiological properties, which can contribute to increased crop yield and soil health. Hence, Haryana's growing system of cotton-wheat and guar-wheat under irrigated conditions in this area due to its potential for increased production, competitiveness and resource conservation.
\end{abstract}

\section{Introduction}

Wheat (Triticum aestivum (L.) and other crops are grown sequentially on approximately $2.5 \mathrm{M}$ ha in irrigated, double crop pattern in the state of Haryana (North-
West India). The annual sequences of rotation used are cotton (Gossypieae)-wheat (Triticum aestivum (L.) in the western part of the state and cluster bean (Cyamopsis tetragonoloba (L.) Taub.)-wheat (Triticum aestivum L.) in the SW regions of Haryana. Cotton-wheat 
cropping system is South Asia's second most effective wheat-based system (4.5 M ha) and India (2.6 M ha) and contributes significantly to food security in the region (Das et al., 2014). Cotton, an important fiber crop, is grown throughout India on an area of 9.5 million hectares ( $\mathrm{M}$ ha) under both rainfed and irrigated conditions (Mayee et al., 2008). Wheat is grown on $29 \mathrm{M}$ ha and meets a number of people's dietary requirements. Both of these crops contribute to the subsistence of a significant number of Indians. Developing short-term early maturing cotton varieties and increasing irrigation facilities has led to the cultivation of a cotton-wheat rotation system in northwestern India. Therefore, the cottonwheat cropping method in the states of Punjab, Haryana and Rajasthan occupies approximately $1.7 \mathrm{M}$ ha (Monga et al., 2009) but cotton production has shown a declining trend in recent years (Mayee et al., 2008).

Cluster bean, known locally as guar, is an important legume cash crop, and is grown as an industrial crop particularly in India's semiarid and arid regions, because of its seeds (guar gum) containing gelling agent, guar cultivation is now gaining ground for a few days, thus having significant industrial use. This crop is a source of nutrient replenishment, particularly nitrogen from soils with low fertility and can withstand the stress of moisture.

Wheat is the most important strategic cereal crop cultivated during the rabi season following semi-arid harvesting of cluster bean. Although these crops are grown under improved irrigation practices coupled with better crop management practices, over the years, the productivity of individual factors has declined (Rajanna et al., 2016).

Water is an abundant natural resource and a gift from the god to sustain all life forms, food production, economic growth and general well-being. To feed ever-increasing population coupled with scarcity and steady reduction in the share of agricultural water. The only one option is to produce more food per unit of water available (Abdin and Salem, 2009). In future, due to competing demands for non-agricultural sectors, the share of water in agriculture will be further reduced by 2050 to approximately 72 to 75 per cent (IWMI, 2002). From which, by non-process depletion, about 52 per cent of the water used by agricultural crops and the remaining 48 per cent is lost.

Minimizing these losses would improve water efficiency considerably through efficient technologies and strategies. Over-exploitation and inadequate groundwater management in many parts of the region has contributed to reduced water level and adverse impacts on the climate. Many persistent problems in the area are the deterioration of land quality due to various types of soil degradation and excess residue burning (Bhattacharyya et al., 2013a,b; Das et al., 2013). Potential resource management technique (RCTs) such as zero tillage, minimal tillage and furrow irrigated raised bed planting (FIRB) which can play a major role in saving scarce natural resources such as water (Hari et al., 2010).

These factors contribute to consideration of agriculture (CA) conservation for sustained production, profitability and soil quality (Kassam et al., 2011). Conservation agriculture has the following four principles: (i) reducing mechanical soil disruption and seeding directly into tilled soil to enhance the quality and health of soil organic matter (SOM); (ii) enhancing the use of SOM to cover crops and/or crop residues (mainly residue retention) (iii) crop diversification in partnerships, sequences and rotations to improve system resilience and (iv) regulated soil compaction traffic. Generally speaking, the benefits of zero tillage derive from the 
three main principles: decreased soil disturbance, enhanced soil cover from crop residues and increased diversity of species by crop rotation (Taroll et al., 2019). The improvement of the chemical and microbiological properties of soil such as SOC, total $\mathrm{N}, \mathrm{P}$ and $\mathrm{K}$, enzymatic activities and microbial counts under zero tillage therefore obey these principles (ParejaSanchez et al., 2017).

CA technologies involving zero-tillage practices, residue management advances (mainly residue retention) to avoid straw burning and crop diversification have potential to increase productivity and soil quality, primarily through SOM build-up (Bhattacharyya et al., 2013a,b). Soil organic carbon is an indicator of soil quality and gives soil matrix structural stability. Under the traditional tillage (CT) method, however, the rate of buildup and potential depletion is significantly reduced (Omara et al., 2017 and 2019). Thus, CA enhances soil organic carbon (SOC) quality, increases efficiency in input usage and has the potential to minimize greenhouse gas emissions (Bhattacharyya et al., $2012 \mathrm{a}, \mathrm{b})$.

The goal of this study was therefore to determine the change in the physico-chemical and microbiological properties associated with the conversion from conventional tillage to zero tillage.

\section{Materials and Methods}

\section{Site and preparation of soil samples}

An experiment on the cotton-wheat and guarwheat cropping system was conducted during 2018 at the research farm of Tigra in Mahendergarh (latitude $28.03^{\circ} \mathrm{N}$ and longitude $76.10^{\circ} \mathrm{E}$ ) after the harvesting of wheat and experimental trials initiated in 2006 to assess the impact of different tillage systems under different crop rotations in Mahendergarh.

The collected soil samples were screened for specific analysis via $2 \mathrm{~mm}$ sieve and stored at $4 \pm 1{ }^{\circ} \mathrm{C}$. In order to establish microbial biomass and microbial activity, the soil was moistened to $60 \%$ water holding capacity (WHC) and incubated for 10 days at $30^{\circ} \mathrm{C}$ to enable uniform rewetting and to enable microbial activity to stabilize after initial disturbances.

\section{Analytical methods:}

\section{Soil texture}

The texture class of the soil was calculated using the textural triangle suggested by the International Society of Soil Sciences (ISSS) from the relative proportion of fractions of sand, silt and clay in the sample.

\section{Soil pH and Electrical Conductivity (EC)}

Five-gram soil was combined with $12.5 \mathrm{ml}$ distilled water to test the $\mathrm{pH}$ and $\mathrm{EC}$ of different soil samples. It was shaken for 30 minutes and the $\mathrm{pH}$ of soil suspension was measured with Systronics $331 \mathrm{pH}$ meter at room temperature, and EC was measured with Naina electrical conductivity meter.

\section{Soil organic carbon}

The organic carbon content in different soil samples was determined by the method of Kalembassa and Jenkinson (1973).

\section{Total N, P and K}

Total nitrogen, phosphorous and potassium content in different soil samples was estimated by Kjeldhal's method (Bremner and Mulvaney, 1982), John (1970) and Knudsen et al., (1982). 


\section{Microbial biomass carbon and nitrogen}

Microbial biomass carbon was estimated by method described by Vance et al., (1987) and microbial biomass $\mathrm{N}$ was estimated by method described by Pruden et al., (1985).

\section{Soil enzyme activities}

Soil dehydrogenase activity was determined by the method of Casida et al., (1964), alkaline phosphatase activity was determined by the method given by Tabatabai and Bremner (1969), cellulase activity was determined by method of Deng and Tabatabai (1995) and soil urease activity was measured by the method of Tabatabai and Bremner (1972).

\section{Enumeration of microorganisms}

Viable counts of bacteria and fungi in different soil samples were determined by serial dilution making and plating on respective media.

\section{Statistical analysis}

To assess the effects of different tillage practices on the soil properties, the RBD statistical programme was used for three way analysis of variance (ANOVA). Computation and preparation of graphs were done using Microsoft Excel 2007 Program.

\section{Results and Discussion}

\section{Soil texture}

The texture of soil samples collected from conventional and conservation tillage plots was sand and mechanical composition of soil under conventional tillage was $92 \%$ sand, 5\% silt and 3\% clay, while under conservational tillage respective values were $89 \%, 6 \%$ and $5 \%$.

\section{Chemical properties}

\section{EC, pH and soil organic carbon}

The data presented in Fig. 1 and 2 on EC and $\mathrm{pH}$ of soils under conventional and zerotillage systems under different crop rotations suggested that not much difference was observed in $\mathrm{EC}$ and $\mathrm{pH}$ of soil at different depths when switching from conventional to zero-tillage. In this research, conservation tillage had little effect on the EC content of Mahendergarh soils at depths of 0-15 and 15$30 \mathrm{~cm}$ compared to traditional tillage, which may be due to the buffering ability of soils based on carbonate content that resisted soil changes in EC during organic matter decomposition under conservation tillage.

These results are supported by Roldan et al., (2005)'s observations that EC was not influenced by tillage practices although, while in contrast, Khan et al., (2017) reported increased EC under NT, which may be attributed to decreased nutrient leaching along with water and increased availability of nutrients under NT. Non-significant effect of ZT or CT was observed by Singh et al., (2015) in loam sand and sandy loam soil, but in contrast to these results Gholami et al., (2014) stated that ZT had the highest EC value compared to $\mathrm{CT}$ because the lower electrical conductivity of the soil under the ZT system compared to $\mathrm{CT}$ related to the increased movement of water in the soil which improved soil aggregate growth. Kumar et al., (2018) found a decrease in soil EC under CT that could be attributed to the opening and aeration of the top soil layers that resulted in increased leaching on the surface soil. In the practice of zero tillage, maximum EC was reported under direct seeded rice with residue application and minimum in traditional tillage practice under transplanted condition (Kevat et al., 2019). 
In present study, not much differences were observed in $\mathrm{pH}$ of soil under $\mathrm{CT}$ and ZT at 015 and 15-30 cm depth and the $\mathrm{pH}$ of soils under CT was 8.0, 8.1 and 7.6, 7.6 at surface and subsurface layer, under cotton-wheat and guar- wheat cropping pattern, respectively, and upon adoption of zero-tillage the values were 8.2, 8.7 and 7.7, 7.6 at $0-15$ and 15-30 cm depth, respectively (Fig. 2). Many researchers have made similar findings. Asenso et al., (2018) found no significant difference under zero-tillage in soil $\mathrm{pH}$ at 0 $40 \mathrm{~cm}$ depth which may be attributed to the fact that no limning material was added as part of the procedure. In contrast, Kumar et al., (2018) documented a significant impact of tillage on soil $\mathrm{pH}$ and observed the highest $\mathrm{pH}$ in zero tillage at the surface layer compared to traditional tillage method, this may be due to the fact that the experiment continued on dry soil agriculture for many years as part of the long term. Tillage does not affect soil $\mathrm{pH}$ directly, but its impact on $\mathrm{pH}$ may depend on the prevailing climate, soil quality, and management factors.

Soil organic matter (SOM) is the material formed by living organisms which are returned to the soil and are decomposed (Bot and Benites, 2005). This increases the soil's physical, chemical, and biologic properties. SOM serves as a source of plant nutrients and water absorbent, and can increase soil productivity by increasing the quality and quantity of organic carbon (SOC) (Lal, 2004). A large amount of literature is available that supports long-term tillage practices that substantially increase soil organic carbon over traditional crop / crop systems (Safeer et al., 2013; Islam et al., 2015; Asenso et al., 2018; Jat et al., 2018; Kumar et al., 2018). In present study, soil organic carbon was relatively higher at $0-15 \mathrm{~cm}$ depth than bottom layer $15-30 \mathrm{~cm}$ depth with the values 0.28 and $0.26 \%$ in conventional tillage, respectively, while respective values under
ZT were $0.31 \%$ and $0.28 \%$ (Fig. 3) in guarwheat rotation. Individually, crop-rotation, tillage and depth affected organic carbon content significantly and our findings are consistent with those of Naresh et al., (2015) and Song et al., (2019) that tillage management practices have a major impact on the overall soil organic carbon (SOC) content at the surface $(0-15 \mathrm{~cm})$ layer relative to $C T$ due to residue preservation, limited disruption and accumulation of organic carbon at the soil surface layer in ZT. Asenso et al., (2018) recorded the highest organic $\mathrm{C}$ below $\mathrm{ZT}$ at a depth of 0-40 cm which could be attributed to undisturbed land resulting in increased soil organic matter accumulation indicating a reduced rate of leaching in the soil surface profile. The findings of other workers' experiences are also endorsed (Hati et al., 2014; Jat et al., 2018; Kaushik et al., 2018; Kumar et al., 2018; Zuber et al., 2018).

\section{Total N, P and K}

Total nitrogen (N), phosphorus (P) and potassium $(\mathrm{K})$ content of different cropping systems is important for maintaining crop productivity and food safety, and a large volume of literature is available to support the fact that long-term ZT increases the total N, P and $\mathrm{K}$ soil content at the surface layer as compared to CT under different cropping systems (Neugschwandtner et al,. 2014; Islam et al., 2015; Zuber et al., 2015). In present study, conservational tillage at different locations was found to affect total N, P and K content under different crop-rotations and higher total $\mathrm{N}, \mathrm{P}$ and $\mathrm{K}$ content was observed under ZT system. There was significant influence of tillage and depth on total $\mathrm{N}, \mathrm{P}$ and $\mathrm{K}$ content at both $0-15$ and $15-30 \mathrm{~cm}$ depth (Fig. 4). Comparison of nutrient status in two farming systems revealed that the total $\mathrm{N}, \mathrm{P}$ and $\mathrm{K}$ content under ZT was $0.049,0.33$ and $0.44 \%$ at surface layer while at subsurface layer the respective values were 
$0.042,0.28$ and $0.39 \%$ under guar wheat cropping system and under $\mathrm{CT}$ the respective vales were $0.044,0.25$ and $0.41 \%$ and 0.040 , 0.18 and $0.35 \%$.

Greater availability of total N, P and K content associated with the zero-tillage at surface layer is closely related to soil organic matter build up. Dorr de Quadros et al., (2012) documented significantly higher total $\mathrm{N}$ and $\mathrm{P}$ content in the no tillage system due to high microbial diversity and high soil organic matter accumulation. In contrast to our findings, Islam et al., (2015) found a nonsignificant interaction impact of tillage on the total $\mathrm{N}, \mathrm{P}$ and $\mathrm{K}$ content of the surface and subsurface layers, but comparatively higher values under zero tillage treatment at the surface layer than the subsurface layer, may be due to an increase in soil organic matter. Similarly, in a comparative study of traditional tillage and no-tillage carried out by Zuber et al., (2015), higher total $\mathrm{N}$ under notillage was reported compared to CT because losses of $\mathrm{N}$ in the form of nitrates leaching and denitrification gaseous losses can offset the addition of $\mathrm{N}$ to the soil and the return of greater crop residue is an important factor in the greater total nitrogen under crop rotation which more frequently incorporates these crops.

\section{Microbiological properties}

No-tillage or conservation tillage preserves or enhances soil quality by maintaining soil structure and moisture, growing soil organic matter, and supplying soil microbes with a home. Most notably it is the bacteria that's why soil microbes are the earth's workhorses.

\section{Microbial biomass carbon and nitrogen}

Soil microbial biomass is a microbial community indicator, i.e. related to soil organic matter quality. In the present study, tillage and depth affected microbial biomass carbon and nitrogen in various soil samples and relatively higher values were observed at the surface layer. MBC and MBN were higher in zero-tillage system as compared to conventional system but the values decreased with depth. The impact of tillage practices on microbial biomass $\mathrm{C}$ and $\mathrm{N}$ in sandy textured soils is shown in Fig. 5. The major affect produced by no-tillage was on $\mathrm{MBC}$ and $\mathrm{MBN}$ at surface layer under CT and ZT.

In present study, the MBC of soils under cotton-wheat and guar-wheat cropping system were 107, 102 and 111, $105 \mathrm{mg} / \mathrm{kg}$ soil at surface and subsurface layer, respectively, under CT and upon adoption of zero-tillage the values were 116, 113 and 124, $116 \mathrm{mg} / \mathrm{kg}$ soil at 0-15 and 15-30 cm depth, respectively. Results of our study are consistent with the findings of Lopez et al., (2013) that microbial biomass carbon under ZT was substantially higher than conventional tillage because tillage conservation resulted in the accumulation of crop residues and organic carbon content at the surface layer. In zero tillage treatment, Chaudhary and Sharma (2019) recorded higher microbial biomass carbon (MB-C) than traditional tillage in the rice-wheat cropping system, showing an increase of $103 \%$ and $46.6 \%$ in MB-C compared to conventional tillage.

During present investigation, the MBN of soils under cotton-wheat and guar-wheat cropping system were 18.1, 15.1 and 19.6 and $16.4 \mathrm{mg} / \mathrm{kg}$ soil at surface and subsurface layer, respectively, under CT and upon adoption of zero-tillage the values were 19.8, 16.5 and $22.5,17.4 \mathrm{mg} / \mathrm{kg}$ soil at $0-15$ and $15-$ $30 \mathrm{~cm}$ depth, respectively. Individually, the effects of crop-rotation, tillage and depth on $\mathrm{MBC}$ and $\mathrm{MBN}$ were significant.

Kabiri et al., (2016) determined the carbon and nitrogen content of soil microbial 
biomass at a depth of $0-20 \mathrm{~cm}$ and reported higher levels of MBC (25-43\%), MBN (7$13 \%), \mathrm{MBC} / \mathrm{MBN}(17 \%)$ compared to conventional tillage. Belmonte et al., (2018) observed the impact of long-term soil management on microbial activity in a vineyard and found higher levels of microbial biomass carbon and nitrogen (106.42 and $13.94 \mathrm{mg} / \mathrm{kg}$ ) in $\mathrm{S}+\mathrm{NT}$ (sown cover crop and no-tillage) followed by UV (under-vine zone with no vegetation and tillage) and least in $\mathrm{S}+\mathrm{T}$ (sown cover crop and tillage) for Vicia faba L., Pisum sativum L., Triticum aestivum
L. Kabiri et al., (2015) and (2016) found that higher microbial biomass carbon and nitrogen contents under no-tillage due to the increased SOM (C and $\mathrm{N}$ ) level probably improved aggregation of soil and higher content of microbial biomass. In contrary, Zuber et al., (2018) found that rotation did not affect microbial biomass $\mathrm{C}$ and $\mathrm{N}$ (MBC, MBN) while conventional tillage reduced $\mathrm{MBN}$ at 10-20 cm compared to NT may be due to soil-wide dispersion of $\mathrm{N}$ fertilizers and $\mathrm{MBN}$ was greater in NT than CT because of SOM accumulation under no-tillage (Table 1-5).

Table.1

\begin{tabular}{|l|l|}
\hline \multicolumn{1}{|c|}{ Factors } & Organic carbon \\
\hline A (crop-rotations) & 0.009 \\
\hline B (Tillage) & 0.009 \\
\hline A X B & NS \\
\hline C (Depth) & 0.009 \\
\hline A X C & NS \\
\hline B X C & NS \\
\hline A XB X C & NS \\
\hline
\end{tabular}

Table.2

\begin{tabular}{|c|c|c|c|c|c|c|c|}
\hline \multirow{2}{*}{$\begin{array}{l}\text { Chemical } \\
\text { properties }\end{array}$} & \multicolumn{7}{|l|}{ Factors } \\
\hline & $\begin{array}{l}\text { A (Crop- } \\
\text { rotations) }\end{array}$ & B (Tillage) & A X B & C (Depth) & $\begin{array}{ll}\mathbf{A} & \mathbf{X} \\
\mathbf{C} & \end{array}$ & $\begin{array}{ll}\text { B } & \mathbf{X} \\
\text { C } & \end{array}$ & $\begin{array}{l}\text { A X B X } \\
\text { C }\end{array}$ \\
\hline Total N & 0.002 & 0.002 & 0.003 & 0.002 & NS & 0.003 & NS \\
\hline Total P & 0.015 & 0.015 & 0.022 & 0.015 & NS & NS & 0.031 \\
\hline Total K & 0.016 & 0.016 & NS & 0.016 & NS & NS & NS \\
\hline
\end{tabular}

C.D. at $5 \%$

Table.3

\begin{tabular}{|l|l|l|}
\hline Factors & MBC & MBN \\
\hline A (Crop-rotations) & 4.007 & 4.007 \\
\hline B (Tillage) & 4.007 & 4.007 \\
\hline A X B & NS & NS \\
\hline C (Depth) & 4.007 & 4.007 \\
\hline A X C & NS & NS \\
\hline B X C & NS & NS \\
\hline AXB X C & NS & NS \\
\hline
\end{tabular}

C.D. at $5 \%$ 
Table.4

\begin{tabular}{|l|c|c|c|c|c|c|c|}
\hline \multirow{2}{*}{$\begin{array}{l}\text { Chemical } \\
\text { properties }\end{array}$} & \multicolumn{7}{|c|}{ Factors } \\
\cline { 2 - 9 } & $\begin{array}{c}\text { A (Crop- } \\
\text { rotations) }\end{array}$ & $\begin{array}{c}\text { B } \\
\text { (Tillage) }\end{array}$ & A X B & C (Depth) & A X & B X C & AXB X C \\
\hline Dehydrogenase & 0.395 & 0.395 & 0.558 & 0.395 & 0.558 & 0.558 & 0.79 \\
\hline $\begin{array}{l}\text { Alkaline } \\
\text { phosphatase }\end{array}$ & 5.925 & 5.925 & 8.379 & 5.925 & 8.379 & 6.729 & 11.85 \\
\hline Cellulase & 0.003 & 0.003 & NS & 0.003 & NS & NS & NS \\
\hline Urease & 0.365 & 0.365 & 0.516 & 0.365 & NS & NS & NS \\
\hline
\end{tabular}

C.D. at 5\%

Table.5

\begin{tabular}{|l|c|c|c|c|c|c|c|}
\hline $\begin{array}{l}\text { Chemical } \\
\text { properties }\end{array}$ & \multicolumn{9}{|c|}{ Factors } \\
\cline { 2 - 8 } & $\begin{array}{c}\text { A (Crop- } \\
\text { rotations) }\end{array}$ & B (Tillage) & A X B & C (Depth) & A X C & B X C & $\begin{array}{c}\text { AXB X } \\
\text { C }\end{array}$ \\
\hline Bacteria & NS & 0.04 & 0.057 & 0.04 & 0.057 & 0.057 & 0.081 \\
\hline Fungi & 0.035 & 0.035 & 0.05 & 0.035 & 0.05 & 0.05 & 0.071 \\
\hline
\end{tabular}

C.D. at $5 \%$

Fig.1 Effect of conventional and zero tillage on EC content under different cropping systems

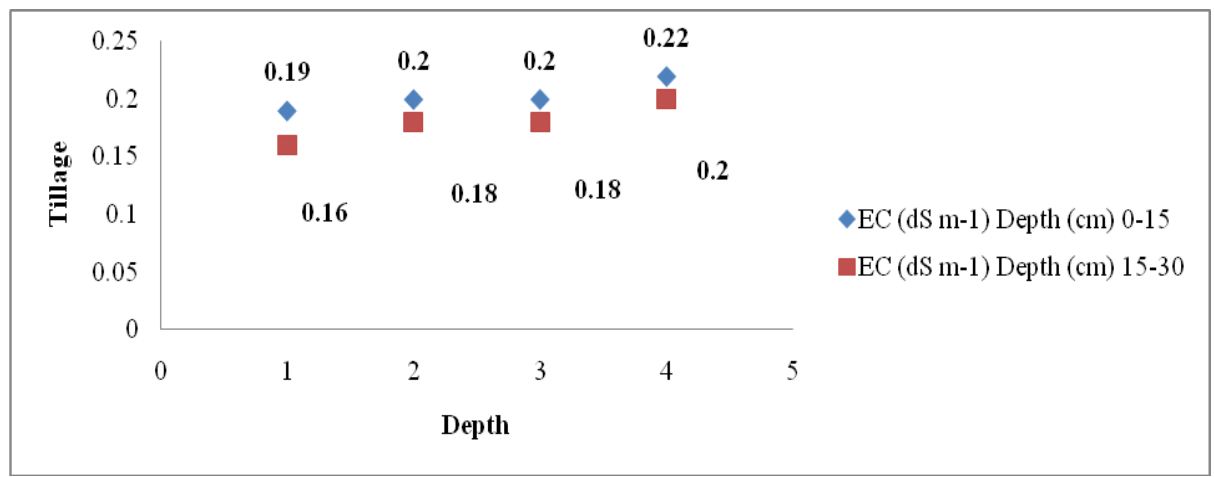

Fig.2 Effect of conventional and zero tillage on $\mathrm{pH}$ content under different cropping systems

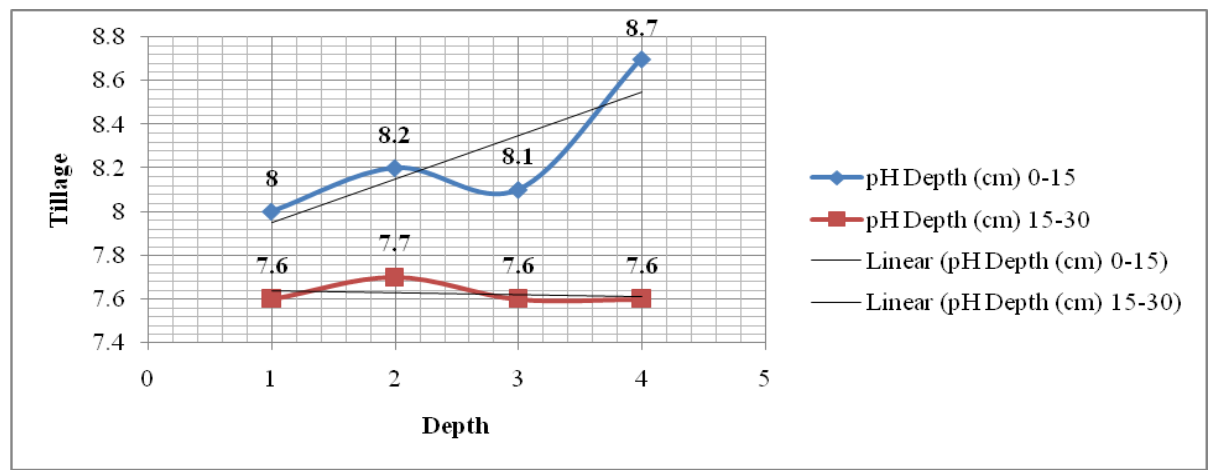


Fig.3 Effect of conventional and zero tillage on soil organic carbon content under different cropping systems

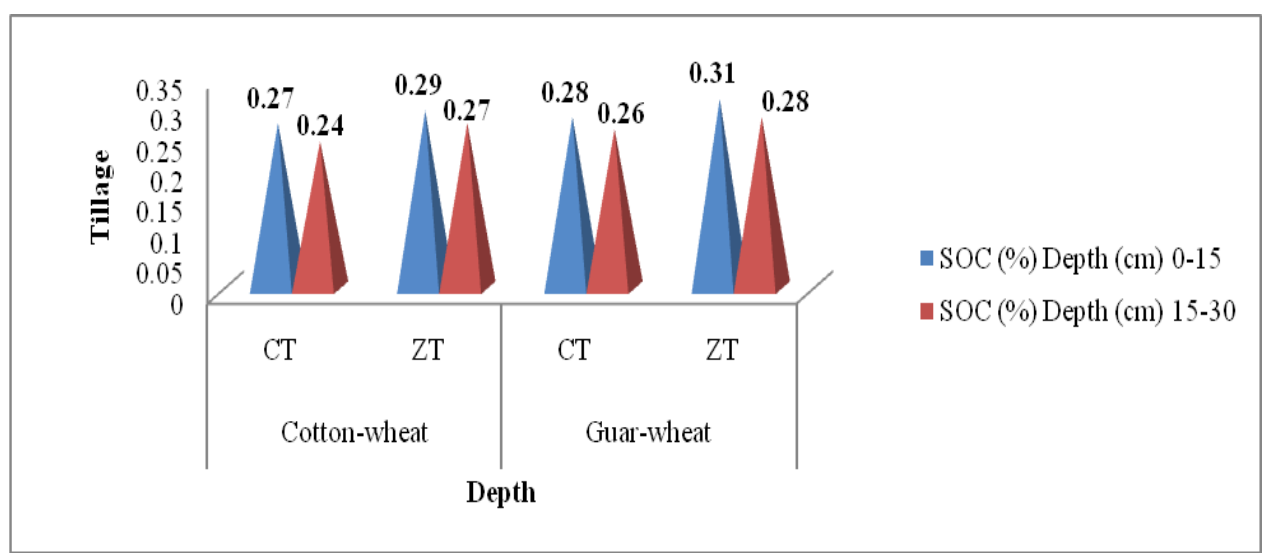

Fig.4

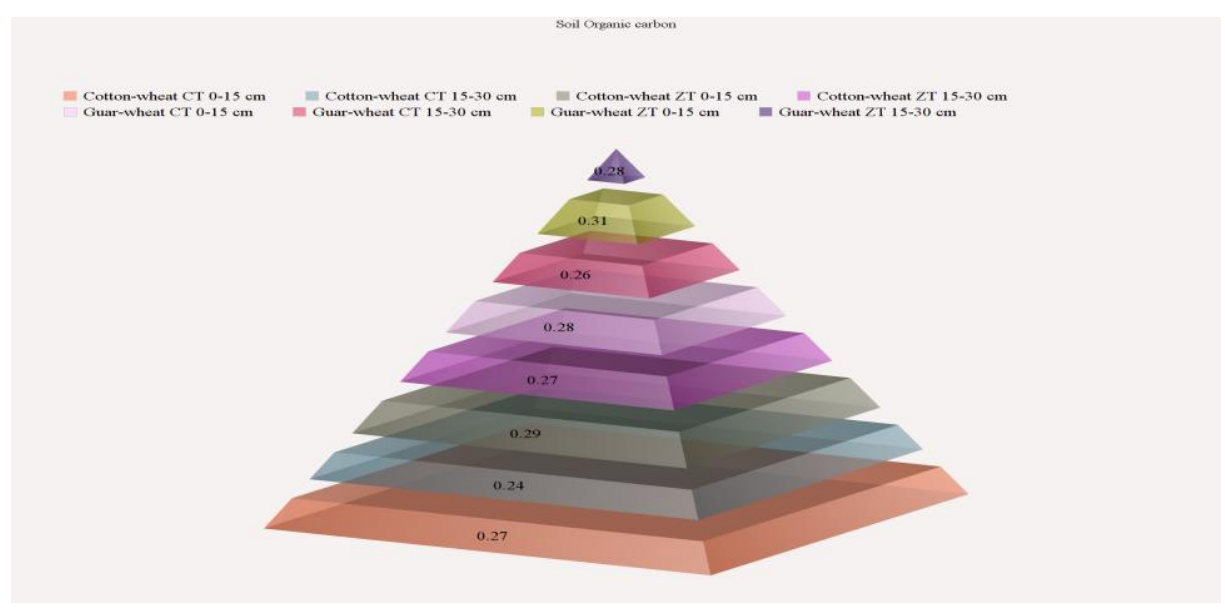

Fig.5 Effect of conventional and zero tillage on Total N, P and K content under different cropping systems

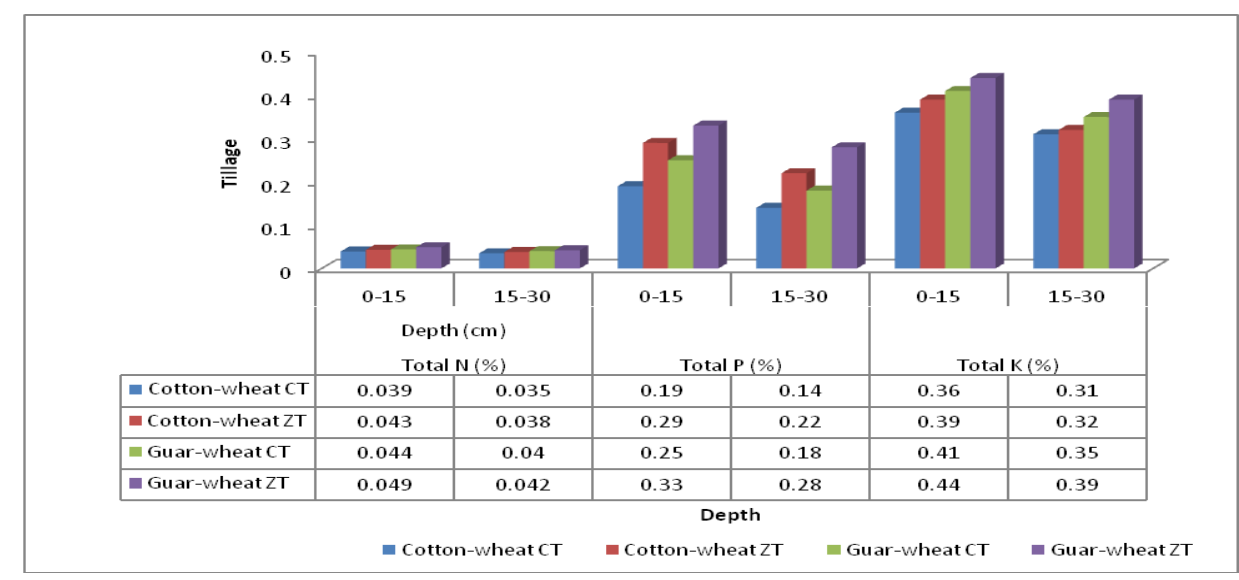


Fig.6 Effect of conventional and zero tillage on microbial biomass carbon and nitrogen content under different cropping systems

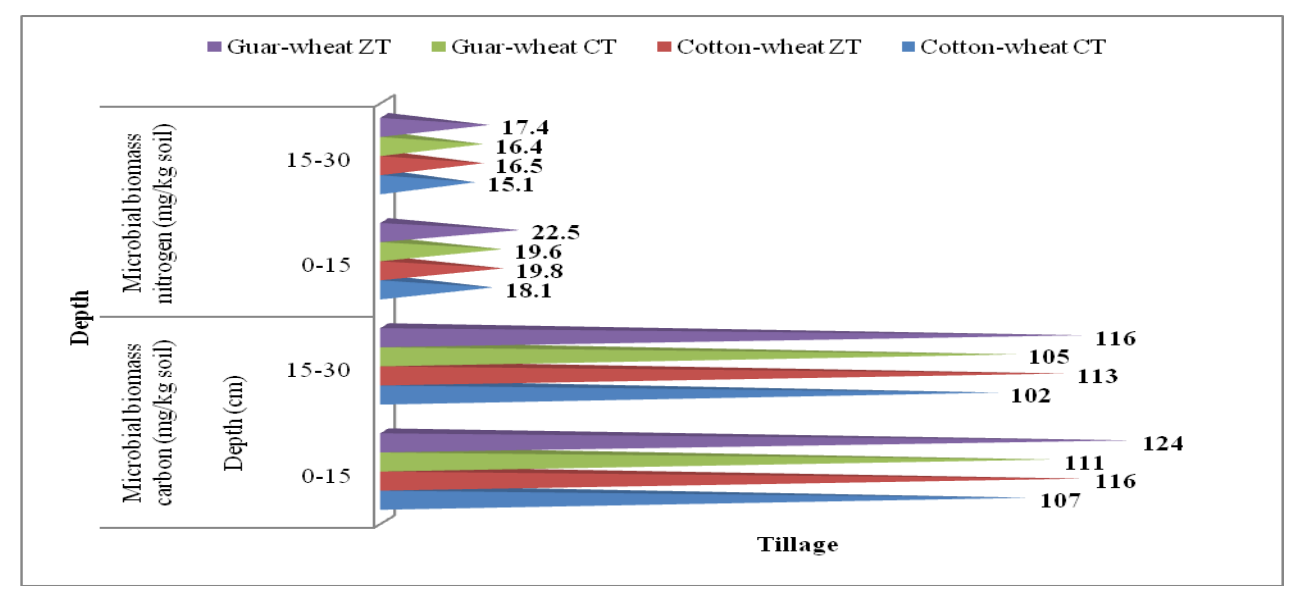

Fig.7 Effect of conventional and zero tillage on enzymatic activity under different cropping systems

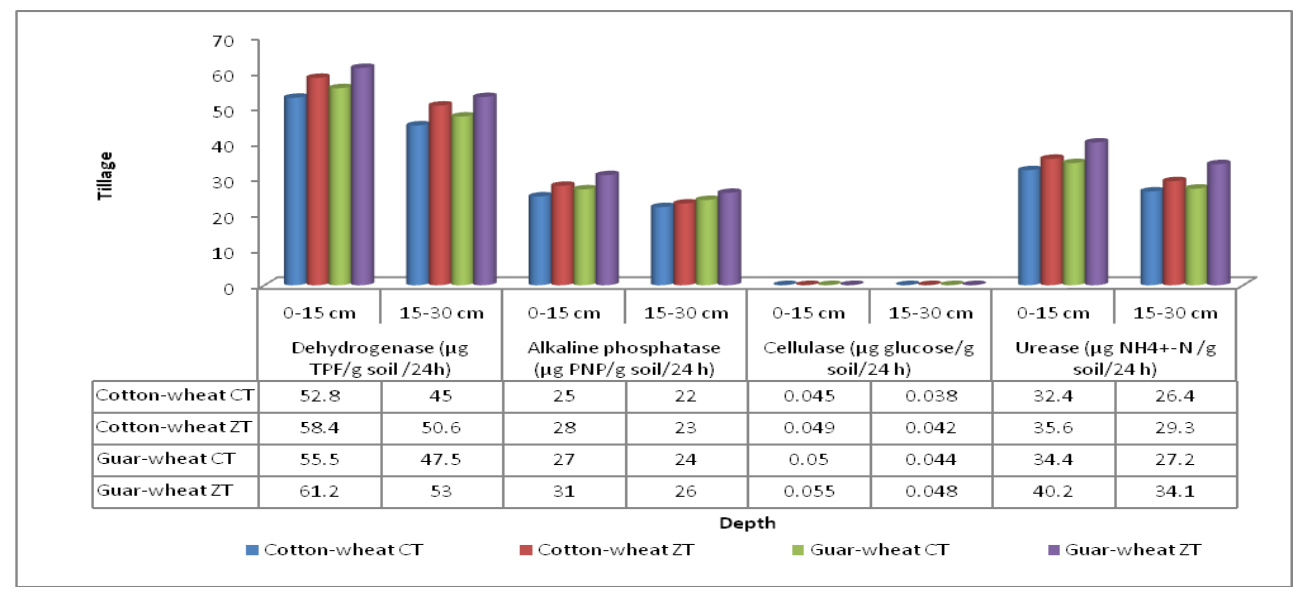

Fig.8 Effect of conventional and zero tillage on microbial count under different cropping systems

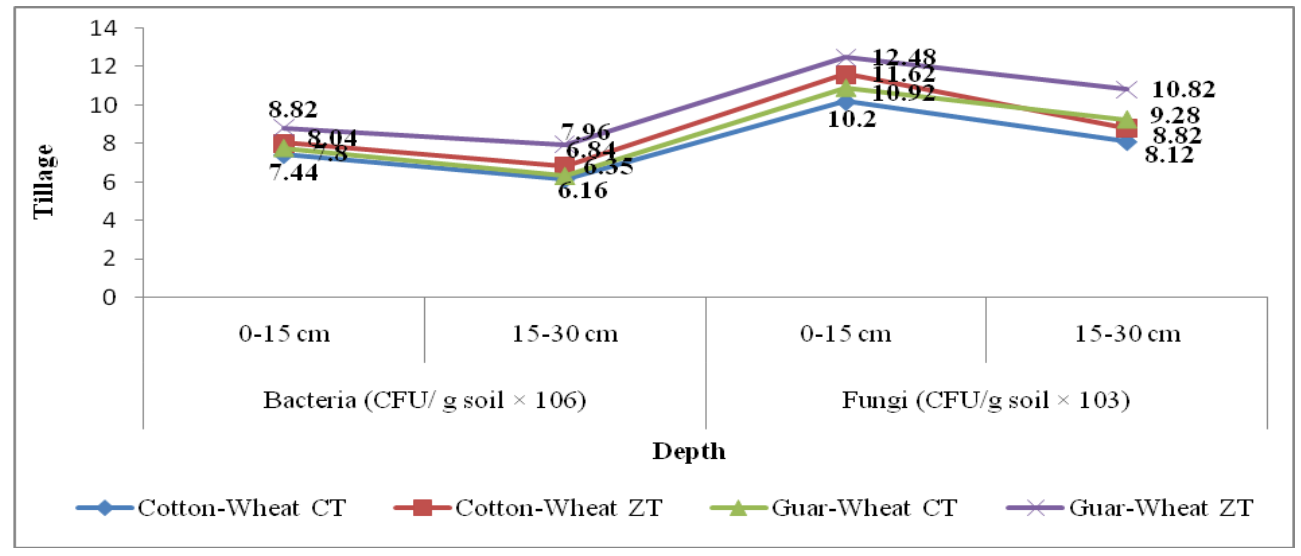




\section{Enzyme activity}

Soil microbial processes are regulated by different enzymes and are influenced by many factors of physical, chemical and environmental significance. Enzymes in soil are biologically important because they affect plant nutrient availability and all microbial activities are directly linked to the various enzymatic activities produced extracellularly by specific microorganisms or plant roots. In soil, the principal sources of enzymes are microorganisms, active roots, and dead cells. Soil enzymatic activity is a delicate marker of the impact on microbial functions of ecological factors. In this study, the effect of soil management practices on different enzymatic activities under different croprotations at different locations viz. Dehydrogenase, alkaline phosphatase, cellulase, and urease were studied, and different enzyme activity was observed higher in the $0-15 \mathrm{~cm}$ layer compared to the $15-30$ $\mathrm{cm}$ layer.

Measurement of dehydrogenase activity (DHA) is one of the analyzes of the overall soil condition, being a highly sensitive indicator of environmental changes (Gałąza et al., 2017). It is closely related to the cycles of carbon and nitrogen, and the biological oxidation of organic soil (Błońska et al., 2016). The activity of dehydrogenase represents the complete oxidizing activity of soil microflora and in present study, DHA was affected with different tillage practices under two cropping systems at 0-15 and 15-30 $\mathrm{cm}$ depth. DHA activity of different soil samples were 52.8, 45.0,55.5 and $47.5 \mu \mathrm{g}$ $\mathrm{TPF} / \mathrm{g}$ soil $/ 24 \mathrm{~h}$ under the conventional tillage system and increased up to 58.4, 50.6 61.2 and $53.0 \mu \mathrm{g}$ TPF/g soil $/ 24 \mathrm{~h}$ at surface and subsurface soil in zero-tillage system, respectively (Fig. 6). Individually and interaction of crop-rotation, tillage and depth was significant. Our results are similar with the findings of Janušauskaite et al., (2013) that the highest dehydrogenase activity at a depth of $0-10 \mathrm{~cm}$ under no-tillage may be attributed to high NT microbial biomass and nutrients than CT. Similarly, Majchrzak et al., 2016 and Bhaduri et al., 2017 observed substantial effect of tillage systems on DHA, which was substantially higher under NT due to accumulation of organic matter and nutrients at the surface layer of soil under notillage.

During present investigation, long term impact of conservational tillage affected the alkaline phosphatase activity in soil. Upon the adoption of zero tillage system, alkaline phosphatase activity was relatively higher under guar-wheat cropping system 31 and 28 $\mu \mathrm{g} \mathrm{PNP} / \mathrm{g}$ soil/ $24 \mathrm{~h}$ at surfaces and subsurface layer, respectively (Fig. 6). Individually and interaction of crop-rotation, tillage and depth was significant. The explanation for increased alkaline phosphatase activity in the surface layer may be due to high concentrations of inorganic phosphate released from organic matter under zero tillage, resulting in increased alkaline phosphatase activity in the surface layer, the results are supported by the findings of that Acosta-Martinez et al., (2003), Mathew et al., (2012) and Gajda et al., (2013).

In present study, cellulase activity in soil under different tillage practices is shown in Fig. 6. Cellulase activity was found higher in guar-wheat cropping pattern at $0-15 \mathrm{~cm}$ depth $(0.055 \mu \mathrm{g}$ glucose/g soil/24 h) and $(0.048 \mu \mathrm{g}$ glucose/g soil/24 h) at $15-30 \mathrm{~cm}$ depth under zero-tillage and cotton-wheat cropping pattern had lower enzymatic activity at surface and subsurface layer $0.049 \mu \mathrm{g}$ glucose $\mathrm{g}^{-1}$ soil 24 $\mathrm{h}^{-1}$ and $0.042 \mu \mathrm{g}$ glucose/g soil/24 $\mathrm{h}$, respectively, with same tillage and the similar trend was observed under conventional tillage. The findings of present study on relatively higher cellulase activity under ZT 
system are contrary to the observation of Mina et al., (2008) and Bini et al., (2014) that no-tillage cellulase production was lower than traditional tillage due to increased organic matter inputs into the soil due to $\mathrm{CT}$ plowing and harrowing, which made organic $\mathrm{C}$ pools more vulnerable to microbial and soil enzyme attacks. However, Balota et al., (2003) reported $90 \%$, increase in cellulase activity under no-tillage as compared with $\mathrm{CT}$ in wheat based cropping systems may be due to high microbial biomass in no-till soils which contained more nutrients than microbial biomass in CT systems.

In present study, urease activity was relatively higher in guar-wheat cropping system at surface soil $\left(40.2 \mu \mathrm{g} \mathrm{NH}_{4}{ }^{+}-\mathrm{N}\right.$ released /g soil/ $24 \mathrm{~h}$ ) which further decreased in subsurface soil $\left(34.1 \mu \mathrm{g} \mathrm{NH}_{4}{ }^{+}-\mathrm{N}\right.$ released $/ \mathrm{g}$ soil/ $\left.24 \mathrm{~h}\right)$ under zero tillage but with conventional tillage system respective values were $(34.4 \mu \mathrm{g}$ $\mathrm{NH}_{4}{ }^{+}-\mathrm{N}$ released /g soil/ $\left.24 \mathrm{~h}\right)$ and $(27.2 \mu \mathrm{g}$ $\mathrm{NH}_{4}{ }^{+} \mathrm{N}$ released /g soil/ $24 \mathrm{~h}$ ) the similar trend was observed in cotton-wheat croprotation under conventional tillage (Fig. 6). The findings of the present study on urease activity under various systems are similar to the observations of Raiesi and Kabiri (2016) that higher urease activity recorded under reduced tillage practices compared to $\mathrm{CT}$ practices may be due to high soil organic carbon accumulation under no-tillage. In comparison, Asenso et al., (2018) found the highest enzyme activity under subsoiling (SS) treatment relative to $\mathrm{ZT}$ treatment since SS treatment loosened the soil and resulted in higher organic $\mathrm{C}$ added to the soil, increasing the abundance of soil microorganisms resulting in increased soil enzyme activity due to increased substratum and oxygen availability.

\section{Microbial count}

The microbial count in soil samples was determined to know the total viable count of bacteria and fungi for studying the impact of tillage practices under different cropping patterns. Compared with traditional tillage, the microbial population increased by implementing zero-tillage and was higher in surface soil under both systems. Bacteria and fungi are a very significant functional group of soil species and involved in many biogeochemical processes. They are responsible for mineralizing organic matter, circulating elements, synthesizing proteins and nucleic acids, as well as transforming phosphorous forms.

In present study the effect of tillage practices on microbial groups under different cropping patterns was studied and population of bacteria and fungi was observed relatively higher in zero tilled soil at $0-15 \mathrm{~cm}$ depth compared to conventional tilled soil and bacteria were most abundant under all systems. The effect of tillage practices on total bacterial population is presented in Fig. 7 revealed that bacterial population remained higher at surface soil and maximum in guarwheat surface soil $8.82 \times 10^{6} \mathrm{cfu} / \mathrm{g}$ soil which further decreased up to $7.96 \times 10^{6} \mathrm{cfu} / \mathrm{g}$ at subsurface layer under zero-tillage practices and cotton-wheat cropping pattern had lower bacterial population at surface and subsurface layer $8.04 \times 10^{6} \mathrm{cfu} / \mathrm{g}$ and $6.84 \times 10^{6} \mathrm{cfu} / \mathrm{g}$, respectively, with same tillage. Similar trend was observed for total microbial count at different depths under two cropping pattern in conventional tillage.

The fungal population in conventional as well as in zero-tillage systems is shown in Fig. 7. There was significant increase in fungal count and maximum in guar-wheat cropping system at surface layer $\left(12.42 \times 10^{3} \mathrm{cfu} / \mathrm{g}\right)$ which further decreased up to subsurface layer $\left(10.48 \times 10^{3} \mathrm{cfu} / \mathrm{g}\right)$ upon adoption of zero tillage practices while cotton-wheat cropping pattern had lower count at surface and subsurface layer $11.62 \times 10^{3} \mathrm{cfu} / \mathrm{g}$ and $8.82 \times 10^{3} \mathrm{cfu} / \mathrm{g}$ respectively and similar trend 
was observed under two cropping pattern at surface and subsurface layer in conventional tillage (Fig. 8).

Such findings are consistent with Dorr de Quadros et al., (2012)'s observations that microbial diversity in the no-tillage environment was substantially higher, as soil management affected soil biodiversity and abundance of individual organisms. Under the conservational agriculture method, Dongre et al., (2017) attributed comparatively higher bacterial and fungal counts at $0-15 \mathrm{~cm}$ depth to submerged conditions in a deeper layer. Schmidt et al., (2018) recorded higher total bacterial number in cover cropped plots at different depths, while no-till treatments showed higher number at surface layer compared to standard tillage because farming practices and depths favored distinctly different microbial life strategies.

In conclusion the soil physico-chemical and microbioloical properties were improved as a consequence of decreased disturbance and crop residue cover on the surface in ZT system. Zero tillage significantly affected the microbial community's functioning as reflected by an increased enzyme activity and in addition, long-term $\mathrm{ZT}$ practice resulted in increased organic carbon, microbial count and aeration status in soils. The study concludes that the practice of $\mathrm{ZT}$ in wheat under various semi-arid IGP crop system in Haryana can be adopted in order to preserve the system's productivity, but the practice must be encouraged in fine textured soils.

\section{References}

Abdin, A. E. and Salem, S. (2009). Strategic plans for sugar cane cultivation in Upper Egypt towards the implementation of rational water use. Egypt Journal of Agricultural Economics, 19(1): 308-333.

Acosta-Martínez, V., Zobeck, T. M., Gill, T. E. and Kennedy, A. C. (2003). Enzyme activities and microbial community structure in semiarid agricultural soils. Biology and Fertility of Soils, 38(4): 216-227.

Asenso, E., Li, J., Hu, L., Issaka, F., Tian, K., Zhang, L., Zhang, L. and Chen, $\mathrm{H}$. (2018). Tillage effects on soil biochemical properties and maize grown in latosolic red soil of southern China. Hindawi. Applied and Environmental Soil Science, 2018: 1-10.

Balota, E. L., Colozzi Filho, A., Andrade, D. S. and Dick, R. P. (2003). Microbial biomass in soils under different tillage and crop rotation systems. Biology and Fertility of Soils, 38 (1): 15-20.

Belmonte, S. A., Celi, L., Stahel, R. J., Bonifacio, E., Novello, V., Zanini, E. and Steenwerth, K. L. (2018). Effect of long-term soil management on the mutual interaction among soil organic matter, microbial activity and aggregate stability in a vineyard. Pedosphere, 28(2): 288-298.

Bhattacharyya, R., Tuti, M. D., Kundu, S., Bisht, J. K., Bhatt, J. C. (2012a). Conservation tillage impacts on soil aggregation and carbon pools in a sandy clay loam soil ofthe Indian Himalayas. Soil Science Society of America Journal, 76: 617-627.

Bhattacharyya, R., Tuti, M. D., Bisht, J. K., Bhatt, J. C., Gupta, H. S. (2012b). Conservation tillage and fertilization impacts on soil aggregation and carbon pools inthe Indian Himalayas under an irrigated rice-wheat rotation. Soil Science, 177: 218-228.

Bhattacharyya, R., Pandey, S. C., Bisht, J. K., Bhatt, J. C., Gupta, H. S., Tuti, M. D., Mahanta, D., Mina, B. L., Singh, R. D., Chandra, S., Srivastva, A. K., Kundu, S. (2013a). Tillage and irrigation effects on soil aggregation and carbon pools in the Indian sub-Himalayas. Agronomy Journal, 105: 101-112.

Bhattacharyya, R., Das, T. K., Pramanik, P., Ganeshan, V., Saad, A. A. and Sharma, A. R. (2013b). Impacts of conservation 
agriculture on soil aggregation and aggregate-associated $\mathrm{N}$ under an irrigated agroecosystem of the IndoGangetic Plains. Nutrient Cycling in Agroecosystems, 96 (2-3): 185-202.

Bhaduri, D., Purakayastha, T. J., Patra, A. K., Singh, M. and Wilson, B. R. (2017). Biological indicators of soil quality in a long-term rice-wheat system on the Indo-Gangetic plain: combined effect of tillage-water-nutrient

management. Environmental Earth Sciences, 76(5): 1-14.

Bini, D., dos Santos, C.A., Bernal, L.P.T., Andrade, G. and Nogueira, M.A. (2014). Identifying indicators of $\mathrm{C}$ and $\mathrm{N}$ cycling in a clayey Ultisol under different tillage and uses in winter. Applied Soil Ecology, 76: 95-101.

Błońska, E., Lasota, J., Gruba, P. (2016). Effect of temperate forest tree species on soil dehydrogenase and urease activities in relation to other properties of soil derived from loess and glaciofluvial sand. Ecological Research, 31: 655-664.

Bot, A. and Benites, J. (2005). The Importance of Soil Organic Matter: Key to DroughtResistant Soil and Sustained Food Production. Food and Agriculture Organization, pp. 78.

Bremner, J. M. and Mulvaney, C. S. (1982). Nitrogen total. In: Page, A. L., Miller, R. H. and Keeny, D. R. (eds.): Methods of Soil Analysis, Part 2, Chemical and Microbiological properties. American Society of Agronomy, Madison, pp. 643698.

Casida, L. E., Klein, D. A. and Santoro, R. (1964). Soil dehydrogenase activity. Soil Science, 98: 371-376.

Chaudhary, A. and Sharma, D. K. (2019). Impact assessment of zero-tillage on soil microbial properties in rice-wheat cropping system. Indian Journal of Agricultural Sciences, 89(10): 1680-3.

Das, T. K., Bhattacharyya, R., Sharma, A. R., Das, S., Saad, A. A., Pathak, H. (2013). Impacts of conservation agriculture on total soil organic carbon retention potential under an irrigated agroecosystem of the western Indo-Gangetic Plains. European Journal of Agronomy, 51: 34-42.

Das, T. K., Bhattacharyya, R., Sudhishri, S., Sharma, A. R., Saharawat, Y. S., Bandyopadhyay, K. K., Sepat, S., Bana, R.S., Aggarwal, P., Sharma, R. K., Bhatia, A., Singh, G., Datta, S.P., Kar, A., Singh, B. Singh, P., Pathak, H., Vyas, A. K. and Jat, M. L. (2014). Conservation agriculture in an irrigated cotton-wheat system of the western Indo-Gangetic Plains: Crop and water productivity and economic profitability. Field Crops Research, 158: 24-33.

Deng, S. P. and Tabatabai, M. A. (1995). Cellulase activity of soils: Effect of trace elements. Soil Biology and Biochemistry, 27: 977-979.

Dongre, K., Sachidanand, B. and Porte, S. S. (2017). Assessment of different microbial population in the rhizosphere of main kharif crop under conventional and conservation agriculture system. International Journal of Current Microbiology and Applied Sciences, 6(9): 813-819.

Dorr de Quadros, P., Zhalnina, K., DavisRichardson, A., Fagen, J. R., Drew, J., Bayer, C., Camargo, F. A. O. and Triplett, E. W. (2012). The effect of tillage system and crop rotation on soil microbial diversity and composition in a subtropical acrisol. Diversity, 4(4): 375395.

Gajda, A. M., Przewłoka, B. and Gawryjołek, K. (2013). Changes in soil quality associated with tillage system applied. International Agrophysics, 27(2): 133-141.

Gałązka, A., Gawryjołek, K., Perzyński, A., Gałązka, R., and Księżak, J. (2017). Changes in enzymatic activities and microbial communities in soil under long-term maize monoculture and crop rotation. Polish Journal of Environmental Studies, 26 (1).

Gholami, A., Asgari, H. R. and Zeinali, E. 
(2014). Effect of different tillage systems on soil physical properties and yield of wheat (Case study: Agricultural lands of Hakim Abad village, Chenaran township, Khorasan Razavi province). International Journal of Advanced Biological and Biomedical Research, 2(5): 1539-52.

Hari, R., Kler, D. S., Yadvinder, S. and Khishan, K. (2010). Productivity of maize (Zea mays)-wheat (Triticum aestivum) system under different tillage and crop establishment practices. Indian Journal of Agronomy, 55(3): 185-190.

Hati, K. M., Singh, R. K., Mandal, K. G., Bandyopadhyay, K. K., Somasundaram, J., Mohanty, M., Sinha, N. K., Chaudhary, R. S. and Biswas, A. K. (2014). Conservation tillage effects on soil physical properties, organic carbon concentration and productivity of soybean-wheat cropping system. Journal of Agricultural Physics, 14(2): 121-129.

Islam, A. K. M. S., Saleque, M. A., Hossain, M. M. and Islam, A. K. M. A. (2015). Effect of conservation tillage on soil chemical properties in rice-maize cropping system. The Agriculturists, 13(2): 62-73.

IWMI, 2002. World water supply and demand, 1995 to 2025. International Water Management Institute, Colombo, Sri Lanka.

Janušauskaite, D., Kadžienè, G. and Auškalnienè, O. (2013). The Effect of tillage system on soil microbiota in relation to soil structure. Polish Journal of Environmental Studies, 22(5): 13871391.

Jat, H. S., Datta, A., Sharma, P. C., Kumar, V., Yadav, A. K., Choudhary, M., Choudhary, V., Gathala, M. K., Sharma, D. K., Jat, M. L., Yaduvanshi, N. P. S., Singh, G. and McDonald, A. (2018). Assessing soil properties and nutrient availability under conservation agriculture practices in a reclaimed sodic soil in cereal-based systems of NorthWest India. Archives of Agronomy and
Soil Science, 64(4): 531-545.

John, M. K. (1970). Colorimetric determination of phosphorus in soil and plant materials with ascorbic acid. Soil Science, 109: 214-220.

Kalembassa, S. J. and Jenkinson, D. S. (1973). A comparative study of titrimetric and gravimetric methods for the determination of organic carbon in soil. Journal of the Science of Food and Agriculture, 24: 1089-1090.

Kabiri, V., Raiesi, F. and Ghazavi, M. A. (2015). Six years of different tillage systems affected aggregate-associated $\mathrm{SOM}$ in a semi-arid loam soil from Central Iran. Soil and Tillage Research, 154: 114-125.

Kabiri, V., Raiesi, F. and Ghazavi, M. A. (2016). Tillage effects on soil microbial biomass, SOM mineralization and enzyme activity in a semi-arid Calcixerepts. Agriculture, Ecosystems and Environment, 232: 73-84.

Kassam, A. H., Stoop, W., Uphoff, N. (2011). Review of SRI modifications in rice crop and water management and research issues for making further improvements in agricultural and water productivity. Paddy and Water Environment, 9: 163180.

Kaushik, U., Raj, D., Rani, P. and Antil, R. S. (2018). Impact of zero tillage on available nutrients status on pearlmillet wheat cropping system. International Journal of Chemical Studies, 6(3): 29973000.

Kevat, T. K., Chowdhury, T., Bhambri, M. C. and Gupta, S. B. (2019). Changes in physico-chemical properties of soil as influenced by conservation agriculture in rice based cropping system of Chhattisgarh. International Journal of Fauna and Biological Studies, 6(1): 1923.

Knudsen, D., Peterson, G. A. and Pratt, P. F. (1982). Lithium, sodium, and potassium. Pages 225-246 in A. L. Page, Ed. Methods of Soil Analysis, Part 2. Chemical and microbiological 
properties. Agronomy No. 9, 2nd ed. American Society of Agronomy, Madison, WI.

Khan, S., Shah, M. A., Wahid, M. A., Rasool, A. and Khan, M. (2017). Impact of tillage practices on soil physical properties, nitrate leaching and yield attributes of maize. Journal of Bioscience and Agriculture Research, 13 (01): 1099-1108.

Kumar, A., Panda, A., Mishra, V. N. and Srivastavaint, L. K. (2018). Short-term effect of conservation tillage on carbon pools under rainfed cropping systems of central India. International Journal of Current Microbiology and Applied Sciences, 7(1): 2040-2053.

Lal, R. (2004). Soil carbon sequestration to mitigate climate change. Geoderma 123: $1-22$.

López, M. V., Arrue, J. L. and Álvaro-Fuentes, J. (2013). Effect of long-term conservation tillage on soil biochemical properties in Mediterranean Spanish areas. Soil and Tillage Research, 105(1): $55-62$.

Mayee, C. D., Monga, D., Dhillon, S. S., Nehra, P. L., Pundhir, P. (2008). CottonWheatProduction System in South Asia: A Success Story. Asia-Pacific Association of Agricultural Research Institutions, Bangkok, pp. 1-48.

Majchrzak, L., Sawinska, Z., Natywa, M., Skrzypczak, G. and GłowickaWołoszyn, R. (2016). Impact of different tillage systems on soil dehydrogenase activity and spring wheat infection. Journal of Agriculture, Science and Technology, 18(20): 18711881.

Mathew, R. P., Feng, Y., Githinji, L., Ankumah, R. and Balkcom, K. S. (2012). Impact of no-tillage and conventional tillage systems on soil microbial communities. Applied and Environmental Soil Science, 2012: 1-10.

Mina, B. L., Saha, S., Kumar, N., Srivastva, A. K. and Gupta, H. S. (2008). Changes in soil nutrient content and enzymatic activity under conventional and zerotillage practices in an Indian sandy clay loam soil. Nutrient Cycling in Agroecosystems. 82(3): 273-281.

Monga, O., Bousso, M., Garnier, P., Pot, V. (2009). Using pore space 3D geometrical modelling to simulate biological activity: Impact of soil structure. Computers and Geosciences, 35: 17891801.

Neugschwandtner, R.W., Liebhard, P., Kaul, H. P. and Wagentristl, H. (2014). Soil chemical properties as affected by tillage and crop rotation in a long-term field experiment. Plant Soil and Environment, 60(2): 57-62.

Naresh, R. K., Gupta, R. K., Gajendra, P., Dhaliwal, S. S. and Kumar, D. (2015). Tillage crop establishment strategies and soil fertility management: resource use efficiencies and soil carbon sequestration in a rice-wheat cropping system. Ecology, Environment and Conservation, 21:127-134.

Omara, P., Macnack, N., Aula, L. and Raun, B. (2017). Effect of long term beef manure application on soil test phosphorus, organic carbon, and winter wheat yield. Journal of Plant Nutrition, 40(8): 11431151.

Omara, P., Aula, L. and Raun, W. R. (2019). Nitrogen uptake efficiency and total soil nitrogen accumulation in long-term beef manure and inorganic fertilizer application. International Journal of Agronomy, 2019: 1-6.

Pruden, G., Kalembassa, S. J. and enkinson, D. S. (1985). Reduction of nitrate prior to Kjeldahl digestion. Journal of the Science of Food and Agriculture, 19: 159-164.

Pareja-Sa'nchez, E., Plaza-Bonilla, D., Ramos, M. C., Lampurlane's, J., A' lvaroFuentes, J. and Cantero-Mart'inez, C. (2017). Long-term no-till as a means to maintain soil surface structure in an agroecosystem transformed into irrigation. Soil and Tillage Research, 
174: 221-230.

Raiesi, F. and Kabiri, V. (2016). Identification of soil quality indicators for assessing the effect of different tillage practices through a soil quality index in a semiarid environment. Ecological Indicators. 71: 198-207.

Rajanna, G. A., Dhindwal, A.S. and Nanwal, R. K. (2016). Irrigation scheduling and crop establishment techniques in cluster beanwheat sequence under semi-arid conditions of India - a review. Annals of Agricultural Research, 37(4): 335-346.

Roldan, A., Salinas-Garc, J. R., Alguacil, M. M., Diaz, E. and Caravaca, F. (2005). Soil enzyme activities suggest advantages of conservation tillage practices in sorghum cultivation under subtropical conditions. Geoderma, 129(3-4):178-185.

Safeer, A., Aziz, I., Mahmood, T. and Akmal, M. (2013). Influence of different tillage practices and earthworm on selected soil physio-chemical parameters and yield of maize. Soil and Environment, 32(2): 114-120.

Schmidt, R., Gravuer, K., Bossange, A. V., Mitchell, J. and Scow, K. (2018). Longterm use of cover crops and no-till shift soil microbial community life strategies in agricultural soil. Plos One. 13(2): 119.

Singh, M., Bhullar, M. S. and Chauhan, B. S. (2015). Influence of tillage, cover cropping, and herbicides on weeds and productivity of dry direct-seeded rice.
Soil and Tillage Research, 147: 39-49.

Song, K., Zheng, X., Lv, W., Qin, Q., Sun, L., Zhang, H. and Xue, Y. (2019). Effects of tillage and straw return on water-stable aggregates, carbon stabilization and crop yield in an estuarine alluvial soil. Scientific Reports, 9(1): 1-11.

Tabatabai, M. A. and Bremner J. M. (1969). Use of p-nitrophenyl phosphate for assay of soil phosphatase activity. Soil Biology and Biochemistry, 1: 301-307.

Tabatabai, M. A. and Bremner J. M. (1972). Assay of urease activity in soils. Soil Biology and Biochemistry, 4: 479-487.

Tarolli, P., Cavalli, M. and Masin, R. (2019). High-resolution morphologic characterization of conservation agriculture. CATENA, 172: 846-856.

Vance, E. D., Brookes, P. C. and Jenkinson, D. S. (1987). An extraction method for measuring soil microbial biomass C. Soil Biology and Biochemistry, 19: 703-707.

Zuber, S. M., Behnke, G. D., Nafziger, E. D. and Villamil, M. B. (2015). Crop rotation and tillage effects on soil physical and chemical properties in Illinois. Agronomy Journal, 107(3): 971978.

Zuber, S. M., Behnke, G. D., Nafziger, E. D. and Villamil, M. B. (2018). Carbon and nitrogen content of soil organic matter and microbial biomass under long-term crop rotation and tillage in Illinois, USA. Agriculture, 8(3): 1-12.

\section{How to cite this article:}

Dhinu Yadav and Leela Wati. 2020. Conservation of Agriculture in the Western Indo-Gangetic Plains' Irrigated Cotton-Wheat and Guar-Wheat System. Int.J.Curr.Microbiol.App.Sci. 9(10): 956-972. doi: https://doi.org/10.20546/ijcmas.2020.910.115 